\title{
測定用の円柱状埋設物による異方性弾性地山の初期（変動） 応力の解析理論
}

\section{THEORY OF THE DETERMINATION OF STRESSES IN AN ANISOTROPIC ELASTIC MEDIUM USING AN INSTRUMENTED SOLID CYLINDRICAL INCLUSION}

\author{
平島 健一*・浜 野浩 幹**
}

By Ken-ichi HIRASHIMA and Hiroki HAMANO

\begin{abstract}
The present paper describes the theoretical aspect of the determination of the stresses in rock unaffected by a borehole with an instrumented cylindrical inclusion which was established by one of the authors (Hirashima). The stress fields of the elastic matrix (isotropic or anisotropic) containing a solid cylindrical inclusion are discussed and the formulae to be used in practice to determine the stresses in rock are presented. The results of calculation by Hirashima's theory and Amadei's theory which has been published recently, are shown by several numerical examples.
\end{abstract}

Keywords: theoretical analysis, field measurements, anisotropy, instrumented inclusion

\section{1. はじめに}

公共的なエネルギー供給や備蓄ならびに交通, 運輸体 系の拡充のためには, 構造物の地下化をはじめ, 各種の 悪質な地質状態を相手にした構造物の設置が要請される が，その基本的な設計の基礎データともいうべき構造物 基盤あるいは構造体設置場所周辺における応力発生, 伝 達機構, 変形挙動あるいは破壊機構の究明と, それらの 地点での初期ならびに変動応力（地圧）の合理的な測定 方法の確立は現時点においても緊急な研究課題である.

しかるに，地山を構成する岩質材料は巨視的には等方 等質にみえる場合でも, 微視的にみれば一般には幾何学 的に複雑な形状と分布を示す同質あるいは異質物質の結 合ないし混合体であり，また，岩石の多くは多結晶質で あってその結晶粒界は力学的に弱点ないし弱面を形成す る.さらにまた, 岩盤をみれば, 一般には亀裂, 節理, 層理などが発達し, 力学的な性質はこれらの存在により 異方性あるいは不連続となるのが普通である.他方では, 地山内部に設置される構造物の形状, 配列, 施工順序等

* 正会員 工博 山梨大学教授 工学部土木工学科 （元400 甲府市武田 4-3-11）

** 正会員 松江工業高等専門学校助教授 土木工学科 （ テ690 松江市西生馬 14-4）
によって周辺地山に生じる応力, 変形挙動は大きく影響 を受けることになる.

これら各種の要因を解明していくための 1 つとして, まず, 岩盤内応力の測定理論の確立を目指した研究をい くつか実施してきた.すなわち, 著者の一人 (平島) は, 実際の岩盤の力学的性質を等質の一般的な三次元異方性 体と仮定した場合の初期 (変動) 応力の測定に関して, ボアホール軸方向に対して平面ひずみ的拘束を仮定した 理論的方法を提案するとともに具体的な数値例を挙げて その処理方法を例示した1).これに対して, Amadei は 著者の論文を受けて, 同様の解析過程により応力解放に 際して平面応力的拘束を仮定して系統的に整理した結果 を取りまとめて発表している21.

この指摘を踏まえて著者らは最近の土木学会論文集 ${ }^{3)}$ において，剛性をもたないボアホール内での計測問題の 場合に対して両者の差異について検討した。

本論文においては，上述した問題に関連して，剛性を 有する埋設型計測器が三次元異方性体（特殊な場合とし て等方性体も含む）の地山に設置された場合の初期（変 動）応力計算に対する基本式を導出するとともに具体的 な数値計算例を挙げてその妥当性を検討したものであ る. また最後に, 平島の平面ひずみ的取り扱いと, Amadei の平面応力的取り扱いとの違いについても数値 
例を挙げて比較検討した. したがって, 本論文は先の著 者らの論文 ${ }^{3)}$ 姉妹編に相当するものである.

\section{2. 解析方 法”}

Fig. 1 に示すように, 直交デカルト座標系 $(x, y, z)$ を設け, $z$ 軸は計測用埋設物の軸方向と一致するように とるものとする. この場合，埋設物の断面形状は円ある いは楕円とし，奥行方向（ $z$ 軸方向）には断面形状は変 化せず，境界（内部あるいは外部の）表面に沿って分布 した物体力および外荷重応力を受けるものとする.なお, これらの物体力および表面力は対象とする地山の母線

(すなわち $z$ 軸方向) に沿っては変化せず一様に分布 しているものとする. また，地山（岩盤）は等質の異方 性弾性体とし，その弾性主軸は系 $(x, y, z)$ の方向 とは独立に一般に任意の方向をもつものとする.

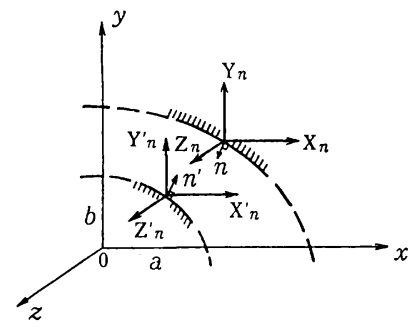

Fig. 1 Coordinates and boundaries of matrix and elliptical inclusion.

\section{（1）直角座標系内における構成方程式}

均質な異方性弾性体の場合の応力ーひずみ関係式（構 成方程式）は一般化 Hooke の法則によって次式で与え られる4),5).

$\left[\begin{array}{c}\varepsilon_{x} \\ \varepsilon_{y} \\ \varepsilon^{z} \\ \gamma_{y z} \\ \gamma_{x z} \\ \gamma_{x y}\end{array}\right]=\left[\begin{array}{llllll}a_{11} & a_{12} & a_{13} & a_{14} & a_{15} & a_{16} \\ a_{12} & a_{22} & a_{23} & a_{24} & a_{25} & a_{26} \\ a_{13} & a_{23} & a_{33} & a_{34} & a_{35} & a_{36} \\ a_{14} & a_{24} & a_{34} & a_{44} & a_{45} & a_{46} \\ a_{15} & a_{25} & a_{35} & a_{45} & a_{55} & a_{56} \\ a_{16} & a_{26} & a_{36} & a_{46} & a_{56} & a_{66}\end{array}\right]\left[\begin{array}{c}\sigma_{x} \\ \sigma_{y} \\ \sigma_{z} \\ \tau_{y z} \\ \tau_{x z} \\ \tau_{x y}\end{array}\right]$

ここに, $a_{i j}$ は弾性コンプライアンスであり, 弾性定数 の逆数に相当する量であって，直交異方性体の特別な場 合で, 座標系 $(x, y, z)$ の座標軸方向と弾性主軸が 一致する場合には次のような関係が成立する.

$$
\begin{aligned}
& a_{11}=\frac{1}{E_{1}}, a_{22}=\frac{1}{E_{2}}, a_{33}=\frac{1}{E_{3}}, a_{12}=-\frac{\nu_{12}}{E_{1}}=-\frac{\nu_{21}}{E_{2}} \\
& a_{13}=-\frac{\nu_{13}}{E_{1}}=-\frac{\nu_{31}}{E_{3}}, a_{23}=-\frac{\nu_{23}}{E_{2}}=-\frac{\nu_{32}}{E_{3}}, a_{44}=\frac{1}{G_{23}} \\
& a_{55}=\frac{1}{G_{31}}, a_{66}=\frac{1}{G_{12}}, \text { その他の } a_{i j}=0
\end{aligned}
$$

ここに, $E_{1}, E_{2}, E_{3}$ は $x, y, z$ 軸方向の主弾性係数
(Young 率), $G_{12}, G_{23}, G_{31}$ は $x-y, y-z, z-x$ 面内 のせん断弾性係数（剛性係数）であり，また， $\nu_{j i}$ は Poisson 比で $j$ 軸方向に作用した一軸荷重応力によって 生じる $j$ 軸方向の直ひずみ $\varepsilon_{j}$ に対するそれに直交する $i$ 軸方向の直ひずみ $\varepsilon_{i}$ の比の絶対值 $\left(\nu_{j i}=\left|\varepsilon_{i} / \varepsilon_{j}\right|\right)$ を 表わす.

いま，円柱状（または楕円柱状）の計測用埋設物の長 さはその直径に比べて十分長いという仮定を設けると， 問題は平面ひずみ状態として取り扱う方が妥当となる. そのため式（1）を次のように変形する. すなわち, 式 (1) の第 3 式より

$$
\sigma_{z}=\frac{\varepsilon_{z}}{a_{33}}-\frac{1}{a_{33}}\left(a_{13} \sigma_{x}+a_{23} \sigma_{y}+a_{34} \tau_{y z}+a_{35} \tau_{x z}+a_{36} \tau_{x y}\right)
$$

これを式（1）に代入すると，その他のひずみ成分は次 のように表わされる。

$$
\left[\begin{array}{c}
\varepsilon_{x} \\
\varepsilon_{y} \\
\gamma_{y z} \\
\gamma_{x z} \\
\gamma_{x y}
\end{array}\right]=\left[\begin{array}{lllll}
\beta_{11} & \beta_{12} & \beta_{14} & \beta_{15} & \beta_{16} \\
\beta_{12} & \beta_{22} & \beta_{24} & \beta_{25} & \beta_{26} \\
\beta_{14} & \beta_{24} & \beta_{44} & \beta_{45} & \beta_{46} \\
\beta_{15} & \beta_{25} & \beta_{45} & \beta_{55} & \beta_{56} \\
\beta_{16} & \beta_{26} & \beta_{46} & \beta_{56} & \beta_{66}
\end{array}\right]\left[\begin{array}{c}
\sigma_{x} \\
\sigma_{y} \\
\tau_{y z} \\
\tau_{x z} \\
\tau_{x y}
\end{array}\right]+\frac{1}{a_{33}}\left[\begin{array}{c}
a_{13} \\
a_{23} \\
a_{34} \\
a_{35} \\
a_{36}
\end{array}\right] \varepsilon_{z}
$$

ここに,

$$
\beta_{i j}=a_{i j}-\frac{a_{i 3} a_{j 3}}{a_{33}}, \quad(i, j=1,2,4,5,6)
$$

同様の式が埋設物 (inclusion) の方にも成立する. ただし，上式で用いられた弾性コンプライアンス $a_{i j}$, $\beta_{i j}$ の代わりに埋設物のそれを用いればよい.

\section{（2）座標変換に伴う弾性定数の変換}

式（1）で示した異方性体の一般化 Hooke の法則の 構成方程式に現われた弾性定数は物体内に設けた座標系 に依存して変化する 4 階のテンソル量である。したがっ て, 異方性体の応力, 変形状態を上述したような直交異 方性体でない最も一般的な場合にも適用しようとする場 合は 1 つの基本坐標系で与えられた弾性定数から所要の 座標変換を実施して求める必要がある.

いま, 基本座標系 $\left(x^{\prime}, y^{\prime}, z^{\prime}\right)$ に対する弾性コンプ ライアンス $a_{i j}^{\prime}$ が既知であるとし，この座標系と原点 $\mathrm{O}$ を共有する, 新しい直交デカルト座標系 $(x, y, z)$ における弾性コンプライアンス $a_{i j}$ はこれら 2 つ座標 系間の方向余弦が Table 1 のように与えられているとす ると，次式で計算できる.

$$
a_{i j}=\sum_{m=1}^{6} \sum_{n=1}^{6} q_{m i} q_{n j} a_{m n}^{\prime}
$$

式（6）に表われる係数 $q_{i j}$ は Table 1 の方向余弦を用 いて計算できる值である ${ }^{5)}$ が，ここでは省略する.

ここで, 具体例として, 直交異方性体の主軸 $x^{\prime \prime \prime}, y^{\prime \prime \prime}$, 
Table 1 Relation between coordinates $(x, y, z)$ and $\left(x^{\prime}, y^{\prime}, z^{\prime}\right)$.

\begin{tabular}{c|c|c|c}
\hline & $x$ & $y$ & $z$ \\
\hline$x^{\prime}$ & $\alpha_{1}$ & $\beta_{1}$ & $\gamma_{1}$ \\
\hline$y^{\prime}$ & $\alpha_{2}$ & $\beta_{2}$ & $\gamma_{2}$ \\
\hline$z^{\prime}$ & $\alpha_{3}$ & $\beta_{3}$ & $\gamma_{3}$ \\
\hline
\end{tabular}

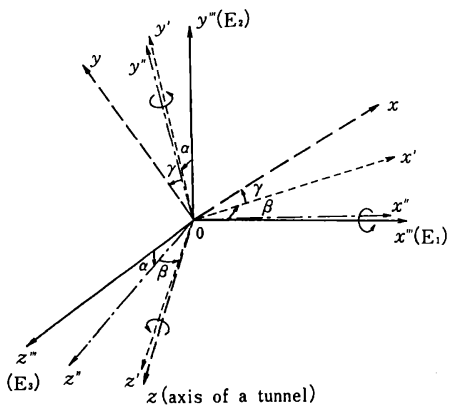

Fig. 2 Transformation of coordinate axes for principal elastic directions.

$z^{\prime \prime \prime}$ が次の手順により角度 $\alpha, \beta, \gamma$ の傾斜をしている場 合を考える (Fig. 2).

すなわち

（1） $\alpha: x^{\prime \prime \prime}$ 軸まわりに回転した角度

（2） $\beta: y^{\prime \prime}$ 軸まわりに回転した角度

$$
\rightarrow \text { 座標系 }\left(x^{\prime \prime}, y^{\prime \prime}, z^{\prime \prime}\right)
$$

（3） $\gamma: z^{\prime}$ 軸まわりに回転した角度

$$
\rightarrow \text { 座標系 }(x, y, z)
$$

のように回転する. 直交異方性体の場合, これらの回転 角 $\alpha, \beta$ および $\gamma$ が $0^{\circ}$ から $90^{\circ}$ までの任意の值をとる ように上述の座標回転を行うと, 任意に選ばれた軸に対 して直交異方性体の主弾性軸があらゆる傾斜をなす場合 の弾性定数が得られる.このような座標変換（回転）を 行うときの新旧座標間の関係（方向余弦）は Table 2 に 示すようなものとなる. したがって, 以上により新座標 系内の弾性定数 $a_{i j}$ が座標回転角 $\alpha, \beta, \gamma$ および旧座 標系での $a_{i j}$ の関数として具体的に求められることにな る.

\section{（3）基礎方程式}

物体力がないとした場合, 応力のつり合い条件式は次 式で与えられる。

$$
\frac{\partial \sigma_{x}}{\partial x}+\frac{\partial \tau_{x y}}{\partial y}=0, \frac{\partial \tau_{x y}}{\partial x}+\frac{\partial \sigma_{y}}{\partial y}=0, \frac{\partial \tau_{x z}}{\partial x}+\frac{\partial \tau_{y z}}{\partial y}=0
$$

いま, 式 $(7)$ を満足するような 2 つの応力関係 $F(x$, $y), \phi(x, y)$ を導入するものとすれば, これらの応力 関数はおのおのの応力成分との間に次式のような関係が 成立する。

$$
\begin{aligned}
& \sigma_{x}=\frac{\partial^{2} F}{\partial y^{2}}, \tau_{x y}=-\frac{\partial^{2} F}{\partial x \partial y} \\
& \sigma_{y}=\frac{\partial^{2} F}{\partial x^{2}}, \tau_{x z}=\frac{\partial \psi}{\partial y}, \tau_{y z}=-\frac{\partial \psi}{\partial x}
\end{aligned}
$$

なお, $z$ 軸に沿う直応力 $\sigma_{z}$ は次式のように求められる.

$$
\begin{aligned}
\sigma_{z}= & A x+B y+C-\frac{1}{a_{33}} \\
& \cdot\left(a_{13} \sigma_{x}+a_{23} \sigma_{y}+a_{34} \tau_{y z}+a_{35} \tau_{z x}+a_{36} \tau_{x y}\right)
\end{aligned}
$$

ここに， $A$ および $B$ はそれぞれ, 考えている物体の $x-z$ 面および $y-z$ 面内の曲げを特性づける定数である.

次に，ひずみ成分あるいは回転成分と変位との間の関 係（幾何学関係式）は, 微小変形の仮定より次式で表わ される.

$$
\begin{aligned}
& \varepsilon_{x}=\frac{\partial u}{\partial x}, \gamma_{x y}=\frac{\partial u}{\partial y}+\frac{\partial v}{\partial x}, 2 \omega_{x y}=\frac{\partial v}{\partial x}-\frac{\partial u}{\partial y} \\
& \varepsilon_{y}=\frac{\partial v}{\partial y}, \gamma_{y z}=\frac{\partial v}{\partial z}+\frac{\partial w}{\partial y}, 2 \omega_{y z}=\frac{\partial w}{\partial y}-\frac{\partial v}{\partial z} \\
& \varepsilon_{z}=\frac{\partial w}{\partial z}, \gamma_{x z}=\frac{\partial w}{\partial x}+\frac{\partial u}{\partial z}, 2 \omega_{x z}=\frac{\partial u}{\partial z}-\frac{\partial w}{\partial x}
\end{aligned}
$$

ただし，上式において，岩盤は無限に広がっており，三 次元的な外荷重は十分遠方より一様に作用すると仮定し ているから，この物体は円柱状埋設物が予定されている $z$ 軸方向には平面ひずみ状態となり，したがって $\varepsilon_{z}$ の みを除いてその他の応力, ひずみ, 変位, 回転は座標 $z$ 亡無関係であると考えられる.すなわち

$$
\frac{\partial u}{\partial z}=\frac{\partial v}{\partial z}=0
$$

が成立するから式（10）は簡単になり結局次のようにな る.

$$
\begin{array}{ll}
\varepsilon_{x}=\frac{\partial u}{\partial x}, \gamma_{x y}=\frac{\partial u}{\partial y}+\frac{\partial v}{\partial x}, 2 \omega_{x y}=\frac{\partial v}{\partial x}-\frac{\partial u}{\partial y} \\
\varepsilon_{y}=\frac{\partial v}{\partial y}, \gamma_{y z}=\frac{\partial w}{\partial y}, & 2 \omega_{y z}=\frac{\partial w}{\partial y} \\
\varepsilon_{z}=\frac{\partial w}{\partial z}, \gamma_{x z}=\frac{\partial w}{\partial x}, & 2 \omega_{x z}=-\frac{\partial w}{\partial x}
\end{array}
$$

Table 2 Relation between coordinates $(x, y, z)$ and $\left(x^{\prime \prime \prime} y^{\prime \prime \prime}, z^{\prime \prime \prime}\right)$.

\begin{tabular}{c|c|c|c}
\hline & $x$ & $y$ & $z$ \\
\hline$x^{\prime \prime \prime}$ & $\cos \beta \cos \gamma$ & $-\cos \beta \sin \gamma$ & $\sin \beta$ \\
\hline$y^{\prime \prime \prime}$ & $\cos \alpha \sin \gamma+\sin \alpha \sin \beta \cos \gamma$ & $\cos \alpha \cos \gamma-\sin \alpha \sin \beta \sin \gamma$ & $-\sin \alpha \cos \beta$ \\
\hline$z^{\prime \prime \prime}$ & $\sin \alpha \sin \gamma-\cos \alpha \sin \beta \cos \gamma$ & $\sin \alpha \cos \gamma+\cos \alpha \sin \beta \sin \gamma$ & $\cos \alpha \cos \beta$ \\
\hline
\end{tabular}


さて, 式 ( 8$)$ の応力関数 $F(x, y)$ および $\phi(x, y)$ は変位の適合条件を満足しなければならないことから, 最終的に次式のような連立偏微分方程式が得られる ${ }^{5)}$.

$$
\begin{aligned}
& L_{4} F+L_{3} \psi=0 \\
& L_{3} F+L_{2} \psi=A a_{34}-B a_{35}
\end{aligned}
$$

ここに， $L_{2}, L_{3}$ および $L_{4}$ は次のような微分演算子であ り, 定数 $A, B$ はいまの場合は零と置いてよい.

$$
\begin{aligned}
L_{2}= & \beta_{44} \frac{\partial^{2}}{\partial x^{2}}-2 \beta_{45} \frac{\partial^{2}}{\partial x \partial y}+\beta_{55} \frac{\partial^{2}}{\partial y^{2}}, \\
L_{3}= & -\beta_{24} \frac{\partial^{3}}{\partial x^{3}}+\left(\beta_{25}+\beta_{46}\right) \frac{\partial^{3}}{\partial x^{2} \partial y}-\left(\beta_{14}+\beta_{56}\right) \frac{\partial^{3}}{\partial x \partial y^{2}} \\
& +\beta_{15} \frac{\partial^{3}}{\partial y^{3}}, \\
L_{4}= & \beta_{22} \frac{\partial^{4}}{\partial x^{4}}-2 \beta_{26} \frac{\partial^{4}}{\partial x^{3} \partial y}+\left(2 \beta_{12}+\beta_{66}\right) \frac{\partial^{4}}{\partial x^{2} \partial y^{2}} \\
& -2 \beta_{16} \frac{\partial^{4}}{\partial x \partial y^{3}}+\beta_{11} \frac{\partial^{4}}{\partial y^{4}} .
\end{aligned}
$$

上式中の $\beta_{i j}$ は式 $(5)$ で与えられる弾性コンプライア ンスである. 以上に示した応力および変位の成分は, 考 えている物体の内部で連続であって座標の一価関数でな ければならない。また，これらの成分を決定するために は, 式（10）を満足し，かつ境界条件を満たすような応 力関数 $F(x, y)$ および $\phi(x, y)$ を定める必要がある.

\section{（4）境界条件}

考えている三次元的な物体の奥行き方向（すなわち， $z$ 軸方向）に変化しないような一様な境界表面を有する 領域の境界周辺に，おのおのの座標軸方向の外荷重応力 $X_{n}, Y_{n}$ および $Z_{n}$ が作用するような第 1 種境界値問題 の場合の境界条件式は次のように与えられる.

$$
\begin{aligned}
& \sigma_{x} \cos (n, x)+\tau_{x y} \cos (n, y)=X_{n} \\
& \tau_{x y} \cos (n, x)+\sigma_{y} \cos (n, y)=Y_{n} \\
& \tau_{x z} \cos (n, x)+\tau_{y z} \cos (n, y)=Z_{n}
\end{aligned}
$$

ここに, $n$ は $z$ 軸に直交して断面の境界表面にたてた 外側方向に向かう法線である。したがって，この法線と $z$ 軸は直交しているからその方向余弦すなわち $\cos (n$,

$z)$ は零であることを考慮したものを採用してある。

また，上式中の方向余弦 $\cos (n, x)$ および $\cos (n$, $y$ ）は境界上の弧長 $s$ によって次のように表わされる.

$$
\begin{aligned}
& \cos (n, x)= \pm \frac{d x}{d n}=\mp \frac{d y}{d s} \\
& \cos (n, y)= \pm \frac{d y}{d n}= \pm \frac{d x}{d s}
\end{aligned}
$$

ここで弧 $s$ は考えている領域が常に左側にあるように 弧上を動くときを正の方向とする．また上式の複符号は 境界の領域が内部にあるとき上側を，境界の領域が外部 のとき下側の符号をとる.なお，Fig. 1 の $X_{n}, Y_{n}$ およ び $Z_{n}$ の方向が正の方向である.
次に境界周縁で変位 $u^{*}, v^{*}$ および $w^{*}$ が与えられて いるような第 2 種境界値問題の場合は

$$
u=u^{*}, v=v^{*}, w=w^{*}
$$

で与えられる。

したがって, 問題は式（15）あるいは式（17）のもと で基礎方程式（13）を解くことにある。

\section{（5）応力関数に対する一般式 5 )}

いま, 式 (13) の連立微分方程式の一般解を次の形で表 わすものとする.

$$
F=F_{0}+F_{1}, \quad \psi=\psi_{0}+\psi_{1}
$$

ここに, $F_{0}(x, y), \phi_{0}(x, y)$ は次の同次方程式

$$
L_{4} F_{0}+L_{3} \psi_{0}=0, L_{3} F_{0}+L_{2} \psi_{0}=0 \text {. }
$$

の一般解であり，また， $F_{1}(x, y), \psi_{1}(x, y)$ は非同次 の連立偏微分方程式 (13) の特別解であり, 式 (13) の 右辺に現われる既知関数の形に依存する.

式 (19) の応力関数 $F(x, y)$ および $\phi(x, y)$ に対 する一般解は次の形をとる.

$$
\begin{aligned}
& F=2 \operatorname{Re}\left[F_{(1)}\left(z_{1}\right)+F_{(2)}\left(z_{2}\right)+F_{(3)}\left(z_{3}\right)\right]+F_{1} \\
& \psi=2 \operatorname{Re}\left[\lambda_{1} F_{(1)}^{\prime}\left(z_{1}\right)+\lambda_{2} F_{(2)}^{\prime}\left(z_{2}\right)+\frac{1}{\lambda_{3}} F_{(3)}^{\prime}\left(z_{3}\right)\right]+\psi_{1}
\end{aligned}
$$

ここに, Re はカッコの中の複素式の実部を示す記号で あり, $F_{(k)}\left(z_{k}\right)$ は複素変数 $z_{k}=x+\mu_{k} y,(k=1,2,3)$ の解析関数である. 係数 $\mu_{k}$ は 6 次の代数方程式の根と して求められる複素数值である. また $\lambda_{k} も \mu_{k}$ が与えら れれば簡単に計算できるものである1),4),5).

（6）応力, 变位成分に対する一般公式

応力, 変位成分に対する一般公式を求めるため, 複素 変数 $z_{k}$ の新しい関数として次式を導入する.

$$
\phi_{k}\left(z_{k}\right)=F_{(k)}^{\prime}\left(z_{k}\right), \phi_{3}\left(z_{3}\right)=\frac{1}{\lambda_{3}} F_{3}^{\prime}\left(z_{3}\right), \quad(k=1,2) \cdots
$$

このような関数を導入すると式（8）および上式から応 力成分に対する一般式は次のように表わされる.

$$
\left.\begin{array}{rl}
\sigma_{x}= & 2 \operatorname{Re}\left[\mu_{1}^{2} \phi_{1}^{\prime}\left(z_{1}\right)+\mu_{2}^{2} \phi_{2}^{\prime}\left(z_{2}\right)+\mu_{3}^{2} \lambda_{3} \phi_{3}^{\prime}\left(z_{3}\right)\right]+\frac{\partial^{2} F_{1}}{\partial y^{2}} \\
\sigma_{y}= & 2 \operatorname{Re}\left[\phi_{1}^{\prime}\left(z_{1}\right)+\phi_{2}^{\prime}\left(z_{2}\right)+\lambda_{3} \phi_{3}^{\prime}\left(z_{3}\right)\right]+\frac{\partial^{2} F_{1}}{\partial x^{2}} \\
\tau_{x y}= & -2 \operatorname{Re}\left[\mu_{1} \phi_{1}^{\prime}\left(z_{1}\right)+\mu_{2} \phi_{2}^{\prime}\left(z_{2}\right)+\mu_{3} \lambda_{3} \phi_{3}^{\prime}\left(z_{3}\right)\right]-\frac{\partial^{2} F_{1}}{\partial x \partial y} \\
\tau_{x z}= & 2 \operatorname{Re}\left[\mu_{1} \lambda_{1} \phi_{1}^{\prime}\left(z_{1}\right)+\mu_{2} \lambda_{2} \phi_{2}^{\prime}\left(z_{2}\right)+\mu_{3} \phi_{3}^{\prime}\left(z_{3}\right)\right]+\frac{\partial \psi_{1}}{\partial y} \\
\tau_{y z}= & -2 \operatorname{Re}\left[\lambda_{1} \phi_{1}^{\prime}\left(z_{1}\right)+\lambda_{2} \phi_{2}^{\prime}\left(z_{2}\right)+\phi_{3}^{\prime}\left(z_{3}\right)\right]-\frac{\partial \psi_{1}}{\partial x} \\
\sigma_{z}= & A x+B y+C-\frac{1}{a_{33}} \\
& \cdot\left(a_{13} a_{x}+a_{23} \sigma_{y}+a_{34} \tau_{y z}+a_{35} \tau_{x z}+a_{36} \tau_{y z}\right)
\end{array}\right\}
$$

変位成分については上式を式（1),（2）に代入して整 
理すれば, 座標軸方向の変位 $u, v$ および $w$ が次のよ うに得られる.

$$
\begin{aligned}
& u=2 \operatorname{Re} \sum_{k=1}^{3} p_{k} \phi_{k}\left(z_{k}\right)+u^{0}-\omega y+u_{0} \\
& v=2 \operatorname{Re} \sum_{k=1}^{3} q_{k} \phi_{k}\left(z_{k}\right)+v^{0}+\omega x+v_{0} \\
& w=(A x+B y+C) a_{33} z+2 \operatorname{Re} \sum_{k=1}^{3} r_{k} \phi_{k}\left(z_{k}\right)+w^{0}+w_{0}
\end{aligned}
$$

ここに， $\omega$ および $u_{0}, v_{0}, w_{0}$ は剛体的な回転および座 標方向の変位を表わす. また, $u^{0}, v^{0}, w^{0}$ は式 (12) の第 1 , 第 2 , 第 5 式および式 (1) から求められる值 であり，さらに， $p_{k}, q_{k}$ および $r_{k}$ は $\beta_{i j}$ と $\mu_{k}$ から計算 できる複素定数である.

境界上で応力 $X_{n}, Y_{n}$ および $Z_{n}$ が与えられるような 第 1 種境界値問題の場合, 断面の境界上での条件として は式（15)，(16）および（22）を利用すれば次式が成立 する.

$$
\begin{array}{r}
2 \operatorname{Re}\left[\phi_{1}\left(z_{1}\right)+\phi_{2}\left(z_{2}\right)+\lambda_{3} \phi_{3}\left(z_{3}\right)\right]=f_{1}(s)-\frac{\partial F_{1}}{\partial x}+c_{1} \\
2 \operatorname{Re}\left[\mu_{1} \phi_{1}\left(z_{1}\right)+\mu_{2} \phi_{2}\left(z_{2}\right)+\mu_{3} \lambda_{3} \phi_{3}\left(z_{3}\right)\right] \\
=f_{2}(s)-\frac{\partial F_{1}}{\partial y}+c_{2} \\
2 \operatorname{Re}\left[\lambda_{1} \phi_{1}\left(z_{1}\right)+\lambda_{2} \phi_{2}\left(z_{2}\right)+\phi_{3}\left(z_{3}\right)\right]=f_{3}(s)-\psi_{1}+c_{3}
\end{array} \mid
$$

ここに,

$$
\begin{aligned}
& f_{1}(s)=\mp \int_{0}^{s} Y_{n} d s, f_{2}(s)= \pm \int_{0}^{s} X_{n} d s, \\
& f_{3}(s)= \pm \int_{0}^{s} Z_{n} d s
\end{aligned}
$$

また $c_{1}, c_{2}, c_{3}$ は断面の領域の境界上で変位 $u^{*}, v^{*}$ および $w^{*}$ が与えられるような第 2 種境界值問題の場合 には次式で表わされる.

$$
\begin{aligned}
& 2 \operatorname{Re} \sum_{k=1}^{3} p_{k} \phi_{k}\left(z_{k}\right)=-U^{0}+U^{*}+\omega y-u_{0} \\
& 2 \operatorname{Re} \sum_{k=1}^{3} q_{k} \phi_{k}\left(z_{k}\right)=-V^{0}+V^{*}-\omega x-v_{0} \\
& 2 \operatorname{Re} \sum_{k=1}^{3} r_{k} \phi_{k}\left(z_{k}\right)=-W^{0}+W^{*}-w_{0}
\end{aligned}
$$

以上により，内部あるいは外部にかかわらず柱状表面 の境界を有する異方性物体のつり合い問題は，3つの複 素関数 $\phi_{k}\left(z_{k}\right)$ を決定することに䚻着する。これらの関 数のおのおのは実在の断面領域 Sにおいて, いろいろ な值に変化する複素変数 $z_{k}\left(=x+\mu_{k} y\right)$ に依存する.

\section{3. 円柱状埋設物を有する地山の応力解析}

前節の基礎的考察をもとに，円柱状埋設物を有する地 山の応力を求める式を導出しよう。いま埋設物をもたな
い岩盤の無限遠に一様な応力成分 $\sigma_{x}^{0}, \sigma_{y}^{0}, \sigma_{z}^{0}, \tau_{y z}^{0}$, $\tau_{x z}^{0}$ および $\tau_{y z}^{0}$ が作用するものとすれば, Airy の応力関 数 $F^{0}$ および $\psi^{0}$ は次式で与えられる.

$$
F_{0}=\frac{1}{2}\left(\sigma_{y}^{0} x^{2}-2 \tau_{x y}^{0} x y+\sigma_{x}^{0} y^{2}\right), \psi^{0}=\tau_{x z}^{0} y-\tau_{y x}^{0} x
$$

ところで，無限に広がった異方性岩盤内に楕円状の埋 設物が存在する場合, この埋設物内に生ずる応力ならび にひずみの場は，埋設物内の位置座標には依存せず，民゙ の場所においても, 無限遠での一様な作用外荷重と同様 に值は異なるが，一様なものになることが証明されてい る6). したがって, 埋設物を有する無限媒体内の応力な らびに変位は次式で与えられる.

$$
\begin{aligned}
& \sigma_{x}=\sigma_{x}^{0}+2 \operatorname{Re}\left[\mu_{1}^{2} \phi_{1}^{\prime}\left(z_{1}\right)+\mu_{2}^{2} \phi_{2}^{\prime}\left(z_{2}\right)+\mu_{3}^{2} \lambda_{3} \phi_{3}^{\prime}\left(z_{3}\right)\right] \\
& \sigma_{y}=\sigma_{y}^{0}-2 \operatorname{Re}\left[\phi_{1}^{\prime}\left(z_{1}\right)+\phi_{2}^{\prime}\left(z_{2}\right)+\lambda_{3} \phi_{3}^{\prime}\left(z_{3}\right)\right] \\
& \tau_{y z}=\tau_{y z}^{0}-2 \operatorname{Re}\left[\lambda_{1} \phi_{1}^{\prime}\left(z_{1}\right)+\lambda_{2} \phi_{2}^{\prime}\left(z_{2}\right)+\phi_{3}^{\prime}\left(z_{3}\right)\right] \\
& \tau_{x z}=\tau_{x y}^{0}+2 \operatorname{Re}\left[\mu_{1} \lambda_{1} \phi_{1}^{\prime}\left(z_{1}\right)+\mu_{2} \lambda_{2} \phi_{2}^{\prime}\left(z_{2}\right)+\mu_{3} \phi_{3}^{\prime}\left(z_{3}\right)\right] \\
& \tau_{x y}=\tau_{x y}^{0}-2 \operatorname{Re}\left[\mu_{1} \phi_{1}^{\prime}\left(z_{1}\right)+\mu_{2} \phi_{2}^{\prime}\left(z_{2}\right)+\mu_{3} \lambda_{3} \phi_{3}^{\prime}\left(z_{3}\right)\right]
\end{aligned}
$$

$$
\begin{aligned}
& u=u^{0}+2 \operatorname{Re} \sum_{k=1}^{3} p_{k} \phi_{k}\left(z_{k}\right)-\omega^{0} y+u_{0} \\
& v=v^{0}+2 \operatorname{Re} \sum_{k=1}^{3} q_{k} \phi_{k}\left(z_{k}\right)+\omega^{0} x+v_{0} \\
& w=w^{0}+2 \operatorname{Re} \sum_{k=1}^{3} r_{k} \phi_{k}\left(z_{k}\right)+w_{0}
\end{aligned}
$$

ここに, $\phi_{k}\left(z_{k}\right), \lambda_{k}, \mu_{k}, p_{k}, q_{k}$ および $r_{k}$ はすでに述 べたように複素解析関数ないしは複素定数であり， $u^{0}$, $v^{0}, w^{0}$ は式 (27) で示される応力関数から求められる $x$, $y, z$ 方向への変位成分である. また, 実定数 $\omega^{0}, u_{0}$, $v_{0}, w_{0}$ は剛体的な回転および剛体的な移動（変位）を 表わすものである.

いま，岩盤と埋設物が完全に付着しているものとすれ ば，それらの接触境界での境界条件は応力ならびに変位 の連続性から次のように書くことができる (Fig.1).

$$
\left.\begin{array}{l}
X_{n}=-X_{n}^{\prime}, Y_{n}=-Y_{n}^{\prime}, Z_{n}=-Z_{n}^{\prime} \\
u=u^{\prime}, v=v^{\prime}, w=w^{\prime}
\end{array}\right\}
$$

ここに, $X_{n}, Y_{n}, Z_{n}$ および $u, v, w$ は岩盤の接触境 界における座標軸方向の応力（表面力）および変位であ り，また，上式の'のついたものは埋設物内の同様の力 学量である.

二,三の計算ののち，これらの境界条件は最終的に次 式となる.

$$
\begin{aligned}
2 \operatorname{Re}\left[\phi_{1}\left(z_{1}\right)+\phi_{2}\left(z_{2}\right)+\lambda_{3} \phi_{3}\left(z_{3}\right)\right] & =\frac{\partial}{\partial x}\left(F^{\prime}-F^{0}\right)+C_{1} \\
2 \operatorname{Re}\left[\mu_{1} \phi_{1}\left(z_{1}\right)+\mu_{2} \phi_{2}\left(z_{2}\right)+\mu_{3} \lambda_{3} \phi_{3}\left(z_{3}\right)\right] & \\
& =\frac{\partial}{\partial y}\left(F^{\prime}-F^{0}\right)+C_{2}
\end{aligned}
$$

$2 \operatorname{Re}\left[\lambda_{1} \phi_{1}\left(z_{1}\right)+\lambda_{2} \phi_{3}\left(z_{3}\right)+\phi_{3}(z)\right]=\psi^{\prime}-\psi^{0}+C_{3}$ 


$$
\begin{aligned}
& 2 \operatorname{Re} \sum_{k=1}^{3} p_{k} \phi_{k}\left(z_{k}\right)=u^{\prime}-u^{0}-\left(\omega^{\prime}-\omega^{0}\right) y+\left(u_{0}^{\prime}-u_{0}\right) \\
& 2 \operatorname{Re} \sum_{k=1}^{3} q_{k} \phi_{k}\left(z_{k}\right)=v^{\prime}-v^{0}+\left(\omega^{\prime}-\omega^{0}\right) x+\left(v_{0}^{\prime}-v_{0}\right) \\
& 2 \operatorname{Re} \sum_{k=1}^{3} r_{k} \phi_{k}\left(z_{k}\right)=w^{\prime}-w^{0}+\left(w_{0}^{\prime}-w_{0}\right)
\end{aligned}
$$

上式中 $C_{1}, C_{2}, C_{3}$ は岩盤の形状および外荷重分布に依 存するものでいくつかの付加的条件から定められるもの である，ただし，今考えている場合には考慮する必要は ない.

さて，埋設物の形状を楕円形で， $x$-および $y$-軸に沿 う半軸を $a$ および $b$ とすれば，この埋設物の境界は次 のように書き表わされる.

$$
x_{0}=a \cos \theta, y_{0}=b \sin \theta
$$

ここに, $\theta$ は $x$ 軸より反時計回りに測った角度である.

式 (27) の $x, y$ の代わりに式 $(33)$ の $x_{0}, y_{0}$ を代 入し，その結果をさらに式（31）に代入すれば次式が得 られる。

$2 \operatorname{Re}\left[\phi_{1}\left(z_{1}\right)+\phi_{2}\left(z_{2}\right)+\lambda_{3} \phi_{3}\left(z_{3}\right)\right] \equiv 2 \operatorname{Re}\left[\bar{a}_{1} e^{-i \theta}\right]$

$2 \operatorname{Re}\left[\mu_{1} \phi_{1}\left(z_{1}\right)+\mu_{2} \phi_{2}\left(z_{2}\right)+\mu_{3} \lambda_{3} \phi_{3}\left(z_{3}\right)\right] \equiv 2 \operatorname{Re}\left[\bar{b}_{1} e^{-i \theta}\right]$

$2 \operatorname{Re}\left[\lambda_{1} \phi_{1}\left(z_{1}\right)+\lambda_{2} \phi_{2}\left(z_{2}\right)+\phi_{3}\left(z_{3}\right)\right] \equiv 2 \operatorname{Re}\left[\bar{c}_{1} e^{-i \theta}\right]$

ここに,

$$
\begin{aligned}
& \bar{a}_{1}=\frac{1}{2}\left\{a\left(\sigma_{y}^{\prime}-\sigma_{y}^{0}\right)-i b\left(\tau_{x y}^{\prime}-\tau_{x y}^{0}\right)\right\} \\
& \bar{b}_{1}=\frac{1}{2}\left\{a\left(\tau_{x y}^{\prime}-\tau_{x y}^{0}\right)-i b\left(\sigma_{x}^{\prime}-\sigma_{x}^{0}\right)\right\} \\
& \bar{c}_{1}=-\frac{1}{2}\left\{a\left(\tau_{y x}^{\prime}-\tau_{y z}^{0}\right)-i b\left(\tau_{x z}^{\prime}-\tau_{x z}^{0}\right)\right\}
\end{aligned}
$$

そこで，楕円孔をもつ岩盤に対する解析関数 $\phi_{k}\left(z_{k}\right)$ は 次式に示すような形式：

$$
\begin{aligned}
& \phi_{k}=\Gamma_{k} \ln \zeta_{k}+\Gamma_{k 1} \zeta_{k}^{-1}, \quad(k=1,2,3) \\
& z_{k}=\frac{1}{2}\left\{\left(a-i \mu_{k} b\right) \zeta_{k}+\left(a+i \mu_{k} b\right) \zeta_{k}^{-1}\right\}
\end{aligned}
$$

に書き表わすことが可能である. 式 (35)，(36) を式 (31) に代入して得られた連立 1 次方程式を解けば次式のよう になる。

$$
\begin{aligned}
& \Delta \cdot \Gamma_{11}=\left(\mu_{2}-\mu_{3} \lambda_{2} \lambda_{3}\right) \bar{a}_{1}+\left(\lambda_{2} \lambda_{3}-1\right) \bar{b}_{1}+\lambda_{3}\left(\mu_{3}-\mu_{2}\right) \bar{c}_{1} \\
& \Delta \cdot \Gamma_{21}=\left(\mu_{3} \lambda_{1} \lambda_{3}-\mu_{1}\right) \bar{a}_{1}+\left(1-\lambda_{1} \lambda_{3}\right) \bar{b}_{1}+\lambda_{3}\left(\mu_{1}-\mu_{3}\right) \bar{c}_{1} \\
& \Delta \cdot \Gamma_{31}=\left(\mu_{1} \lambda_{2}-\mu_{2} \lambda_{1}\right) \bar{a}_{1}+\left(\lambda_{1}-\lambda_{2}\right) \bar{b}_{1}+\left(\mu_{2}-\mu_{1}\right) \bar{c}_{1} \\
& \Delta=\mu_{2}-\mu_{1}+\lambda_{2} \lambda_{3}\left(\mu_{1}-\mu_{3}\right)+\lambda_{1} \lambda_{3}\left(\mu_{3}-\mu_{2}\right)
\end{aligned}
$$

次に，埋設物内の忘力を決定するための解析手順につ いて考える. まず，岩盤内に埋設物がないとした場合の 変位 $u^{0}, v^{0}, w^{0}$ を定める. ひずみ, 回転および変位の 関係は式 $(10)$ において $u, v, w$ および $\omega$ を $u^{0}, v^{0}$, $w^{0}$ および $\omega^{0}$ に，また, $\varepsilon_{x}, \varepsilon_{y}, \cdots, \omega_{x z}$ を $\varepsilon_{x}^{0}, \varepsilon_{y}^{0}, \cdots$, $\omega_{x z}^{0}$ に置き換えたものになり，この式において式 (11)
の関係が成立する. その式を積分すると

$$
\begin{aligned}
& u^{0}=\varepsilon_{x}^{0} x+\frac{1}{2} \gamma_{x y}^{0} y-\omega_{x y}^{0} y+u_{0} \\
& v^{0}=\varepsilon_{y}^{0} y+\frac{1}{2} \gamma_{x y}^{0} x+\omega_{x y}^{0} x+v_{0} \\
& w^{0}=\gamma_{x z}^{0} x+\gamma_{y z}^{0} y+\varepsilon_{z}^{0} z+w_{0}
\end{aligned}
$$

が得られる. 同様にして埋設物内の変位は式 (38) のサ フィックス 0 を'に置き換えた形で得られる。これらの 変位を式 $(32)$ に代入すると次のようになる.

$$
\begin{aligned}
& u^{\prime}-u^{0}-\left(\omega^{\prime}-\omega^{0}\right) y+\left(u_{0}^{\prime}-u_{0}\right) \\
& =\left(\varepsilon_{x}^{\prime}-\varepsilon_{x}^{0}\right) x+\frac{1}{2}\left(\gamma_{x y}^{\prime}-\gamma_{x y}^{0}-2 \omega\right) y \\
& v^{\prime}-v^{0}+\left(\omega^{\prime}-\omega^{0}\right) x+\left(v_{0}^{\prime}-v_{0}\right) \\
& =\left(\varepsilon_{y}^{\prime}-\varepsilon_{y}^{0}\right) y+\frac{1}{2}\left(\gamma_{x y}^{\prime}-\gamma_{x y}^{0}+2 \omega\right) x \\
& w^{\prime}-w^{0}+\left(w_{0}^{\prime}-w_{0}\right) \\
& =\left(\gamma_{x z}^{\prime}-\gamma_{x z}^{0}\right) x+\left(\gamma_{y z}^{\prime}-\gamma_{y z}^{0}\right) y+\left(\varepsilon_{z}^{\prime}-\varepsilon_{z}^{0}\right) z \\
& \omega=\left(\omega^{\prime}-\omega^{0}\right)+\left(\omega_{x y}^{\prime}-\omega_{x y}\right)
\end{aligned}
$$

式 (39)，(37）を式（32）に代入し整理すると次式が求 められる。

$$
\begin{aligned}
& 2 \sum_{k=1}^{3} p_{k} \Gamma_{k 1}=a\left(\varepsilon_{x}^{\prime}-\varepsilon_{x}^{0}\right)+\frac{1}{2} i b\left(\gamma_{x y}^{\prime}-\gamma_{x y}^{0}-2 \omega\right) \\
& 2 \sum_{k=1}^{3} q_{k} \Gamma_{k 1}=\frac{1}{2} a\left(\gamma_{x y}^{\prime}-\gamma_{x y}^{0}+2 \omega\right)+i b\left(\varepsilon_{y}^{\prime}-\varepsilon_{y}^{0}\right) \\
& 2 \sum r_{k} \Gamma_{k 1}=a\left(\gamma_{x z}^{\prime}-\gamma_{x z}^{0}\right)+i b\left(\gamma_{y z}^{\prime}-\gamma_{y z}^{0}\right)
\end{aligned}
$$

ただし，ここで円柱状（または楕円柱状）埋設物の長さ はその直径に比べて十分に長いという仮定から，埋設物 内の $z$ 方向ひずみ $\varepsilon_{z}^{0}$ と等しいと仮定して解析を進め る. 式 (40) に式（4），(22）に対応する式を利用し, 次に式 (35)〜 (37) を用いれば最終的に6つの未知定数 $\sigma_{x}, \sigma_{y}, \tau_{y z}, \tau_{x z}, \tau_{x y}$ および $\omega$ に関する 6 個の連立 1 次方程式が得られる.したがって,これを解くことによっ て埋設物内に生じる一様な応力 $\sigma_{x}, \sigma_{y}, \tau_{y z}, \tau_{x z}, \tau_{x y}$ および相対回転 $\omega$ が得られることになる.ただし，こ の計算は連立方程式の係数が複素数となるため電子計算 機のプログラム上で行う必要がある. 物体内のもう $1 つ$ の応力成分 $\sigma_{z}$ は, ひずみ $\varepsilon_{z}$ が $\varepsilon_{z}^{0} に$ 等しいということ から次式で算出される.

$$
\begin{aligned}
\sigma_{z}^{\prime} & =\frac{\varepsilon_{z}^{0}}{\alpha_{23}^{\prime}}-\frac{1}{a_{33}^{\prime}}\left(a_{13}^{\prime} \sigma_{x}^{\prime}+a_{23}^{\prime} \sigma_{y}^{\prime}+a_{34}^{\prime} \tau_{y z}^{\prime}+a_{35}^{\prime} \tau_{x z}^{\prime}+a_{36}^{\prime} \tau_{x y}^{\prime}\right) \\
\varepsilon_{z}^{0} & =a_{13} \sigma_{x}^{0}+a_{23} \sigma_{y}^{0}+a_{33} \sigma_{z}^{0}+a_{34} \tau_{y z}^{0}+a_{35} \tau_{x z}^{0}+a_{36} \tau_{x y}^{0}
\end{aligned}
$$

上述した方法を使うことにより，逆に埋設物内の計測 装置により測定した一様な応力成分 $\sigma_{x}, \sigma_{y}, \cdots, \tau_{x y}$ から, 岩盤の無限遠より働く応力 $\sigma_{x}^{0}, \sigma_{y}^{0}, \cdots, \tau_{x y}^{0}$ を一義的に 
決定することが可能になる.

以上が著者らの一人 (平島) がかつて確立した異方性 岩盤に対する初期（変動）応力の算定のための基本的な 理論の枠組である1)が，これに対し Amadei は最近この 考え方を補正する論文を発表した ${ }^{21}$. その差異は以上に 示した理論において用いられているボアホール軸 $(z$ 軸) 方向に対して平面ひずみとしての弾性コンプライアンス $\beta_{i j}$ を平面応力状態に対応する弾性コンプライアンス $a_{i j}$ に置き換えて地山の初期（変動）応力を計算しようとす るものである. したがって, Amadei の理論をここで再 記することはしないが，次節の計算例でその取扱いの差 異がどの程度のものとなるか具体例で示すこととする.

\section{4. 数値計算例}

前節に示した理論解析過程により, 地山岩盤内の無限 遠より作用する応力成分 $\sigma_{x}^{0}, \sigma_{y}^{0}, \sigma_{z}^{0}, \tau_{y z}^{0}, \tau_{x z}^{0}$ および $\tau_{x y}^{0}$ が埋設物内の応力成分から次式のような形で決定で きることになる.

$$
\begin{array}{r}
\sigma_{i}^{0}=F_{i}^{1} \sigma_{x}^{\prime}+F_{i}^{2} \sigma_{y}^{\prime}+F_{i}^{3} \sigma_{z}^{\prime}+F_{i}^{4} \tau_{y z}^{\prime}+F_{i}^{5} \tau_{x z}^{\prime}+F_{i}^{6} \tau_{x y}^{\prime} \\
(i=x, y, z) \\
\tau_{i j}^{0}=H_{i j}^{1} \sigma_{x}^{\prime}+H_{i j}^{2} \sigma_{y}^{\prime}+H_{i j}^{3} \sigma_{z}^{\prime}+H_{i j}^{4} \tau_{y z}^{\prime}+H_{i j}^{5} \tau_{x z}^{\prime}+H_{i j}^{6} \tau_{x y}^{\prime} \\
(i, j=x, y, z, i \neq j)
\end{array}
$$

ここに, $F^{k}, H_{i j}^{k}(k=1,2, \cdots, 6)$ は岩盤および埋設物 に関する弾性定数とそれらの方向が与えられるならば定 まる定数である. これらの係数 $F_{i}^{k}, H_{i j}^{k}$ は埋設物内で 測定された応力 $\sigma_{i}, \tau_{i j}$ によって岩盤内の応力 $\sigma_{i}^{0}, \tau_{i j}^{0}$ を決定するいわゆる応力影響係数と名付けることができ るものである. いいかえれば，これらの応力影響係数が 前もって計算されておれば，岩盤の応力成分を式 (42) で見出すことができることになる.

（1）岩盤および埋設物がともに等方性の場合の応力 影慗係数

円柱状 $(a=b)$ の埋設物の弾性定数を

$$
E_{0}=3.0 \times 10^{4} \mathrm{~kg} / \mathrm{cm}^{2}, \quad \nu_{0}=0.360
$$

として計算を行う. 影響係数のうち $F_{i}^{4}, F_{i}^{5}, H_{i j}^{1}, H_{i j}^{2}$, $H_{i j}^{3}, H_{y z}^{5}, H_{y z}^{6}, H_{x z}^{4}, H_{x z}^{6}, H_{x y}^{4}$ および $H_{x y}^{5}$ は岩盤お よび埋設物がともに等方性であるという仮定から零とな る. 残りの影響係数を岩盤の Young 係数 $E$ および Poisson 比 $\nu$ をパラメーターとして図示したものが Fig.3である.これは平面ひずみとしての取扱い（平島 理論 $)^{11}$ によって求めたものである.

\section{（2）岩盤が異方性の場合の応力影霎係数}

埋設物の弾性性質は等方性で (1) の場合と同様の弾 性定数をとるものとする．また，地山岩盤は次のような 弾性定数をとる横等方性体とする.

$$
E_{2}=E_{3}=6.0 \times 10^{4} \mathrm{~kg} / \mathrm{cm}^{2}, \quad \nu_{12}=\nu_{13}=0.150
$$

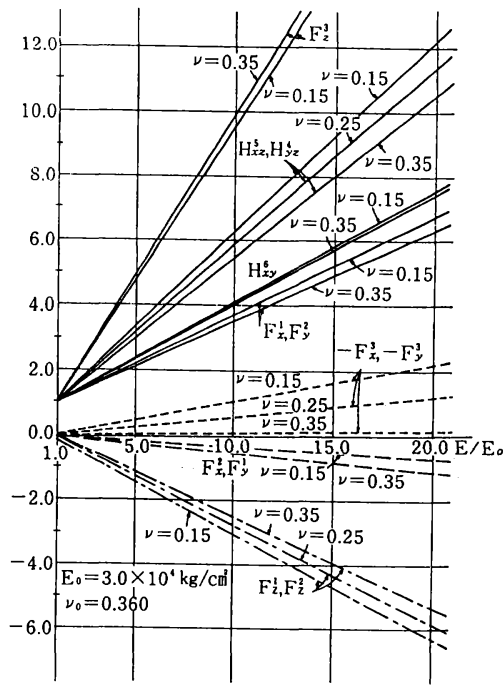

Fig. 3 Influence coefficients of stress $F_{i}^{k}$ and $H_{i j}^{k}$ when the matrix and cylindrical inclusion are both isotropic bodies (Young's modulus and Poisson's ratio of the inclusion are respectively, $E_{0}=3.0 \times 10^{4} \mathrm{~kg} / \mathrm{cm}^{2}$ and $\nu_{0}=$ 0.360 ) due to Hirashima's theory by the assumption of plane strain.

$\nu_{23}=0.250$

なお, せん断弾性係数は

$$
\frac{1}{G_{i j}}=\frac{1}{E_{i}}+\frac{1}{E_{j}}+\frac{2 \nu_{t j}}{E_{i}} \quad(i, j=1,2,3)
$$

で定義されるような値をとるものと仮定する．この異方 性岩盤の主弾性方向は任意の方向をもっていてよいが, その主弾性方向と座標系 $(x, y, z)$ との関係は式 ( 6 ) で示したような座標変換関係にあるものとする. 埋設物 の $z$ 軸（軸方向）に垂直な面内（すなわち $x y$ 面）に対 して岩盤の主弾性方向が面内および面外に傾斜する場合 についての応力影響係数の值を図示したものがそれぞれ Fig. 4 および Fig. 5 である.

Fig. 4(a)，（b)，(c) は主弾性係数 $E_{1}$ （または $E_{2}$ ) が $z$ 軸に関して面内回転する場合の主弾性係数比 $e=$ $E_{1} / E_{2}=E_{1} / E_{3}$ がいくつかの代表的な值をとるものと し，平面ひずみとしての取扱い (平島理論) によって求 めた結果である。これらの図中には係数 $F_{y}^{k}$ および $H_{y z}^{k}$ の結果が与えられていないが,これらの係数は次式から 決定される.

$$
\left(F_{y}^{k}\right)_{\gamma}=\left(F_{x}^{k}\right)_{\gamma=90^{\circ}-\gamma}, \quad\left(H_{y z}^{k}\right)_{\gamma}=\left(H_{y z}^{k}\right)_{\gamma}=\left(H_{x z}^{k}\right)_{\gamma=90^{\circ}-\gamma}
$$

ここに, $\gamma$ は Fig. 2 に示したように $z^{\prime \prime}$ 軸まわりの回転 角である.

Fig. 5(a)〜(d) は主弾性係数 $E_{1}$ および $E_{2}$ を含む面 が $y^{\prime \prime}$ 軸に関して面外方向に傾斜した場合の影響係数を 図示したものである. 


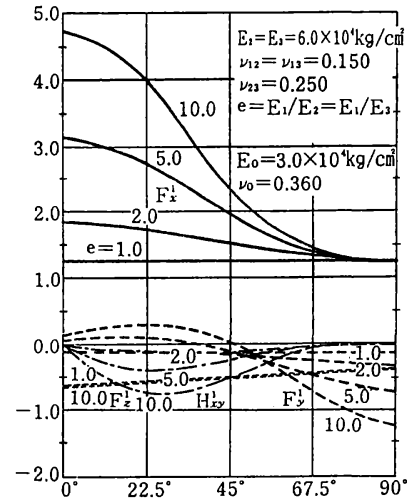

(a) $\gamma\left(\alpha=\beta=0^{\circ}\right)$

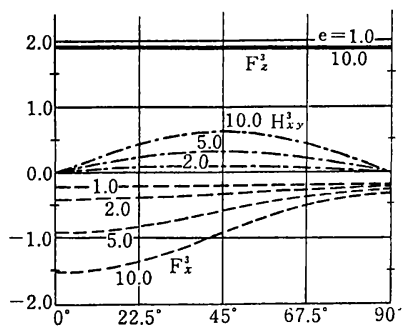

(b) $\gamma\left(\alpha=\beta=0^{\circ}\right)$

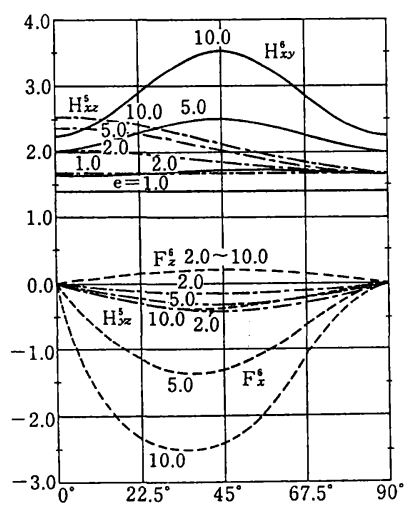

(c) $\gamma\left(\alpha=\beta=0^{\circ}\right)$

Fig. 4 Influence coefficients of stress $F_{i}^{k}$ and $H_{\iota j}^{k}$ when the Young's moduli $E_{1}$ and $E_{2}$ of the matrix rotates inplane with respect to the $z$-axis due to Hirashima's theory by the assumption of plane strain.

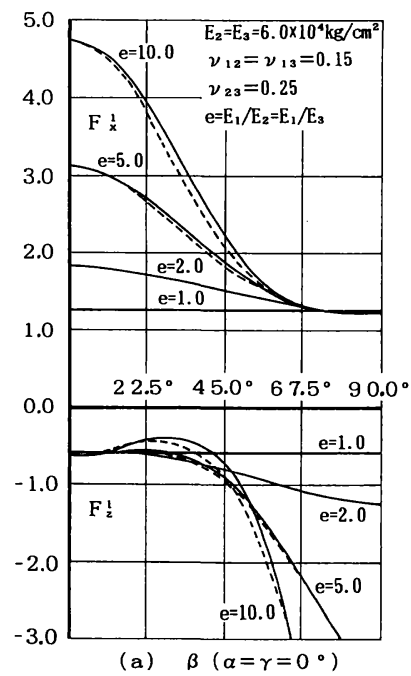

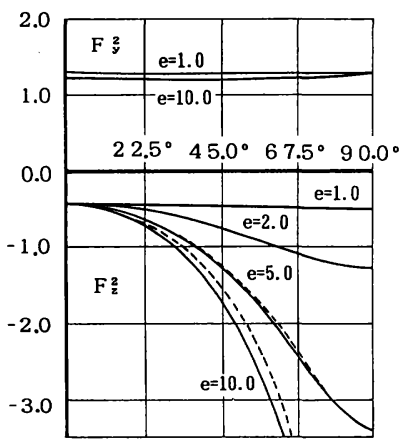

(b) $\beta\left(\alpha=\gamma=0^{\circ}\right)$

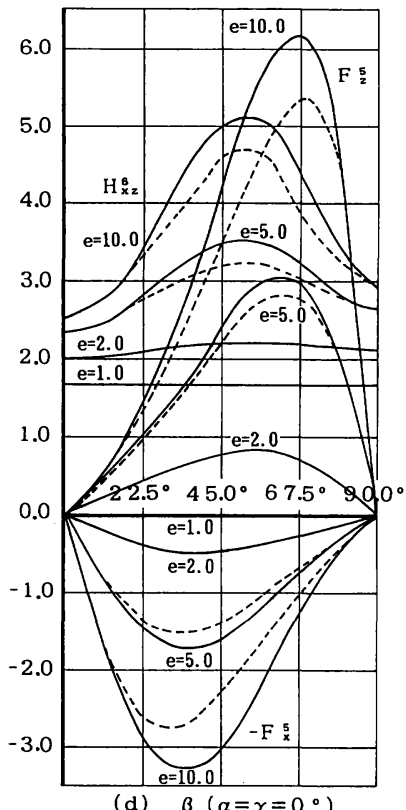

Fig. 5 Influence coefficients of stress $F_{i}^{k}$ and $H_{i j}^{k}$ when the plane containing the principal directions of $E_{1}$ and $E_{2}$ of the matrix rotates out-of-plane with respect to the $y$-axis for the cases of Hirashima's theory (solid lines) and Amadei's theory (dotted lines). 


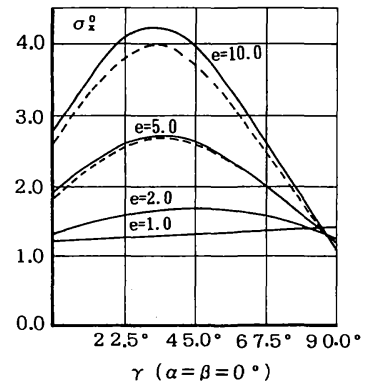

Fig. 6 Different effects of Hirashima's theory (solid lines) and Amadei's theory (dotted lines) on matrix (ground) stress component $\sigma_{x}^{0}$.

実線が平面ひずみ，点線が平面応力として取り扱った 場合の結果を示しており，e が相対的に小さいうちはそ の差異はほとんどないが， $e$ が大きくなるにつれて，両 理論による差異は増大する. たとえば $e=10.0$ で, $\beta$ が $45^{\circ}$ 付近では $20 \sim 30 \%$ 程度の差が生じている. した がって,この場合は初期 (変動) 応力の值にそれなりの 影響を及ぼすことになる．そのことをいま少し，検証し たものが Fig. 6 であり, これは $\alpha=0, \beta=22.5^{\circ}$ とし, $\gamma$ を $0^{\circ} \sim 90^{\circ}$ に変化させた場合の初期 (変動) 地山応力 成分 $\sigma_{x}^{0}$ を, パラメーター $e$ を変動させて求めた結果で ある. $e$ が大きくなるにつれて両理論間の值に差異が生 じてくることが観察される.

以上は計算図表の一例であるが，これらの図表を利用 して岩盤内の無限遠に作用する三次元応力を決定するこ とが可能である．たとえば，岩盤と埋設物の弾性定数が 前もって計測されておれば，それらの值を用いて Fig. 3 ～6に示したような応力影響係数の図が作成できる. そ こで，たとえば，計測装置を備えた埋設物内の応力成分 がオーバーコアリングなどの応力測定法によって次の值 のように測定されたものとする.

$\sigma_{x}^{\prime}=2.0 \mathrm{~kg} / \mathrm{cm}^{2}, \quad \sigma_{y}^{\prime}=3.5 \mathrm{~kg} / \mathrm{cm}^{2}, \quad \sigma_{z}^{\prime}=4.3 \mathrm{~kg} / \mathrm{cm}^{2}$ $\tau_{y z}^{\prime}=1.5 \mathrm{~kg} / \mathrm{cm}^{2}, \tau_{x z}^{\prime}=1.0 \mathrm{~kg} / \mathrm{cm}^{2}, \tau_{x y}^{\prime}=-1.2 \mathrm{~kg} / \mathrm{cm}^{2}$

この場合の埋設物の弾性定数を $E_{0}=3.0 \times 10^{4}$ $\mathrm{kg} / \mathrm{cm}^{2}, \nu_{0}=0.360$, 岩盤の弾性定数およびそれらの傾 斜角を

$$
\begin{aligned}
& E_{2}=E_{3}=4.0 \times 10^{4} \mathrm{~kg} / \mathrm{cm}^{2} \\
& G_{12}=G_{13}=4.0 \times 10^{4} \mathrm{~kg} / \mathrm{cm}^{2} \\
& G_{23}=1.6 \times 10^{4} \mathrm{~kg} / \mathrm{cm}^{2}, \quad \nu_{12}=\nu_{13}=0.20 \\
& \nu_{23}=0.250 \\
& e=E_{1} / E_{2}=E_{1} / E_{3}=1.0,5.0 \text { および } 10.0 \\
& \alpha=0^{\circ}, \beta=22.5^{\circ}, \quad \gamma=0^{\circ}, 45^{\circ} \text { および } 90^{\circ}
\end{aligned}
$$

\begin{tabular}{|c|c|c|c|c|c|c|c|c|}
\hline e & $\gamma$ & Theory & $\sigma_{\mathrm{x}}^{0}$ & $\sigma_{y}^{0}$ & $\sigma_{z}^{0}$ & $\tau_{x y}^{0}$ & $\tau_{\mathrm{xz}}^{0}$ & $\tau_{\mathrm{Y} z}^{0}$ \\
\hline \multirow{3}{*}{10} & $0^{\circ}$ & $\begin{array}{l}\text { (A) } \\
\text { (B) }\end{array}$ & $\begin{array}{l}2.725 \\
2.386\end{array}$ & $\begin{array}{l}3.078 \\
3.100\end{array}$ & $\begin{array}{l}4.830 \\
4.672\end{array}$ & $\begin{array}{l}-2.518 \\
-2.142\end{array}$ & $\begin{array}{l}2.358 \\
2.155\end{array}$ & $\begin{array}{l}4.224 \\
3.933\end{array}$ \\
\hline & $45^{\circ}$ & $\begin{array}{l}\text { (A) } \\
\text { (B) }\end{array}$ & $\begin{array}{l}1.012 \\
1.115\end{array}$ & $\begin{array}{l}4.928 \\
4.321\end{array}$ & $\begin{array}{l}4.629 \\
4.347\end{array}$ & $\begin{array}{l}-2.037 \\
-1.745\end{array}$ & $\begin{array}{l}3.746 \\
3.365\end{array}$ & $\begin{array}{l}2.703 \\
2.684\end{array}$ \\
\hline & $90^{\circ}$ & $\begin{array}{l}\text { (A) } \\
\text { (B) }\end{array}$ & $\begin{array}{l}1.504 \\
1.500\end{array}$ & $\begin{array}{l}3.058 \\
3.155\end{array}$ & $\begin{array}{l}3.965 \\
4.011\end{array}$ & $\begin{array}{l}-1.361 \\
-1.347\end{array}$ & $\begin{array}{l}1.557 \\
1.546\end{array}$ & $\begin{array}{l}1.800 \\
1.745\end{array}$ \\
\hline \multirow{3}{*}{5} & $0^{\circ}$ & $\begin{array}{l}\text { (A) } \\
\text { (B) }\end{array}$ & $\begin{array}{l}2.225 \\
2.154\end{array}$ & $\begin{array}{l}3.088 \\
3.097\end{array}$ & $\begin{array}{l}4.611 \\
4.588\end{array}$ & $\begin{array}{l}-2.526 \\
-2.150\end{array}$ & $\begin{array}{l}1.979 \\
1.919\end{array}$ & $\begin{array}{l}4.212 \\
3.911\end{array}$ \\
\hline & $45^{\circ}$ & $\begin{array}{l}\text { (A) } \\
\text { (B) }\end{array}$ & $\begin{array}{l}.738 \\
.996\end{array}$ & $\begin{array}{l}4.679 \\
4.221\end{array}$ & $\begin{array}{l}4.397 \\
4.268\end{array}$ & $\begin{array}{l}-1.766 \\
-1.637\end{array}$ & $\begin{array}{l}3.453 \\
3.191\end{array}$ & $\begin{array}{l}2.973 \\
2.823\end{array}$ \\
\hline & $90^{\circ}$ & $\begin{array}{l}\text { (A) } \\
\text { (B) }\end{array}$ & $\begin{array}{l}1.519 \\
1.517\end{array}$ & $\begin{array}{l}3.151 \\
3.187\end{array}$ & $\begin{array}{l}4.018 \\
4.035\end{array}$ & $\begin{array}{l}-1.347 \\
-1.340\end{array}$ & $\begin{array}{l}1.543 \\
1.534\end{array}$ & $\begin{array}{l}1.753 \\
1.733\end{array}$ \\
\hline \multirow{3}{*}{1} & $0^{\circ}$ & $\begin{array}{l}\text { (A) } \\
\text { (B) }\end{array}$ & $\begin{array}{l}1.533 \\
1.624\end{array}$ & $\begin{array}{l}3.217 \\
3.193\end{array}$ & $\begin{array}{l}4.353 \\
4.431\end{array}$ & $\begin{array}{l}-2.580 \\
-2.182\end{array}$ & $\begin{array}{l}1.271 \\
1.238\end{array}$ & $\begin{array}{l}4.134 \\
3.775\end{array}$ \\
\hline & $45^{\circ}$ & $\begin{array}{l}\text { (A) } \\
\text { (B) }\end{array}$ & $\begin{array}{r}.379 \\
.759 \\
\end{array}$ & $\begin{array}{l}4.450 \\
4.064\end{array}$ & $\begin{array}{l}4.129 \\
4.121\end{array}$ & $\begin{array}{l}-1.348 \\
-1.341\end{array}$ & $\begin{array}{l}2.878 \\
2.634\end{array}$ & $\begin{array}{l}3.415 \\
3.168\end{array}$ \\
\hline & $90^{\circ}$ & $\begin{array}{l}\text { (A) } \\
\text { (B) }\end{array}$ & $\begin{array}{l}1.640 \\
1.644\end{array}$ & $\begin{array}{l}3.303 \\
3.285\end{array}$ & $\begin{array}{l}4.184 \\
4.167\end{array}$ & $\begin{array}{l}-1.308 \\
-1.314\end{array}$ & $\begin{array}{l}1.484 \\
1.474\end{array}$ & $\begin{array}{l}1.780 \\
1.770\end{array}$ \\
\hline
\end{tabular}

とした場合の三次元地山応力成分を計算した結果を Table 3 に示した．両理論による差異は $e$ が大きくなる
Table 3 Difference between Hirashima's theory and Amadei's theory for stress components in matrix (ground).

(A) : Assumption of plane strain (Hirashima's theory)

(B): Assumption of plane stress (Amadei's theory).

に従って, 相対的に大きな差異が生じているが，この差 は平島が平面ひずみ状態を仮定して弾性係数を式（5） に従った $\beta_{i j}$ を用いているのに対して, Amadei は平面 応力状態を仮定して $\beta_{i j}$ の代わりに $a_{i j}$ を用いて計算し ていることに起因する. 両理論の適用性, 妥当性ないし は適用範囲等に対する考察について, 著者らの先の論 文 ${ }^{3}$ における考察結果を参照して頂きたい，なお，ここ で示した地山岩盤に作用する初期（変動）応力の数値結 果はたとえば，Fig.5〜6にみるように平面応力とした 取扱いによる場合 (Amadei 理論) よりも大きめに計算 される傾向にあり，したがって前者の理論（平島理論） は設計に際しての安全側の予測値を与える傾向にあるこ とを指摘しておく

\section{5. おわりに}

本論文では岩盤を均質であるが三次元異方性体と仮定 し, その内部に, 直径に比べて十分長い円柱状（あるい は棈円柱状）埋設物がある場合の応力および変位を計算 するための一般的な基礎式を導いた．また，応力影響係 数という考えを導入することにより，岩盤と埋設物の弾 性定数が前もってわかっており，さらに埋設物内の応力 成分がオーバーコアリング等の応力測定法によって測定 されているような場合の岩盤の応力を数値計算によって 求めた。この理論計算過程において，平面ひずみ的取扱 い (平島理論) と平面応力的取扱い (Amadei 理論) と の差異を具体例を通して明らかにした。

\section{参 考 文 献}

1) Niwa, Y. and Hirashima, K. : The theory of the determination of stress in an anisotropic elastic medium using 
an instrumented cylindrical inclusion, Mem. Fac. Eng., Kyoto Univ., Vol. 36, pp. 221 232, 1971; Hirashima, K. and Koga, A. : Determination of stresses in anisotropic elastic medium unaffected by boreholes from measured strains or deformations, Proc. Symp. Field Measurements in Rock Mechanics, Zurich, pp. 173 -182, 1977.

2) Amadei, B. : Rock Anisotropy and the Theory of Stress Measurements, Springer-Verlag, 478 pp. 1983.

3）平島健一・浜野浩幹：異方性弾性地山内の応力測定理論 に関する二, 三の再考察, 土木学会論文集, 第 382 号／ III-7, pp. 141 147, 1987.

4) Lekhnitskii, S. G. : Anisotropic Plates, (Eng. Trans.),
Gordon and Breach Science Publishers, New York, pp. 190 197, 1968.

5) Lekhnitskii, S. G. : Theory of Elasticity of an Anisotropic Elastic Body, (Eng. Trans.), Holden-Day Inc., pp. 103 162, 1983.

6) Eshelby, D. : The Determination of the Elastic Field of an Ellipsoidal Inclusion, and Related Problems, Proc. Roy. Soc., A 241, pp. 376 396, 1957; Elastic Inclusions and Inhomogeneities, Progress in Solid Mechanics, 2, (eds. I. N. Sneddon and R. Hill), North-Holland, pp. 89 $\sim 140,1961$.

(1988.9.10 - 受付) 